\title{
EFFECT OF DIFFERENT ROOF CONFIGURATIONS ON THERMAL PERFORMANCE OF SOLAR STILLS
}

\author{
*El-Sheikh, I. H. and **Kishk, S. S.
}

\section{ABSTRACT}

The goal of this study was to evaluate the thermal performance of four identical solar stills with different roof shapes. Four solar stills with similar basin area with different roof glass cover configurations were designed, installed and tested at the Agricultural Engineering Department, Faculty of Agriculture, Suez Canal University, Ismailia Governorate, Egypt (latitude angle of $30.62^{\circ} \mathrm{N}$, Longitude angle of $32.27^{\circ} \mathrm{E}$, and mean altitude above the sea level of $5 \mathrm{~m}$ ). The solar stills had four different roofs, single slope, downward slanting cover, double slope, and pyramidal shape. The basin of each solar still made of galvanized iron sheet, with a net upper surface area of $0.42 \mathrm{~m}^{2}$. It was painted with matt black paint to absorb the maximum possible amount of solar radiation incident on it. In the bottom and sides of the basin, $0.03 \mathrm{~m}$ of Styrofoam insulation was placed to reduce the heat losses. The obtained results indicated that the productivity of four solar stills was 116, 107, 84 and $72 \mathrm{ml} / \mathrm{hr}$ with average thermal efficiency of 33.7, 31.0, 24.7 and $21.2 \%$ for the single slope, downward slanting, double slope, and pyramidal roofs, respectively.

\section{INTRODUCTION}

7 he solar distillation is one of the most important methods for producing fresh water from brackish and sea water using the free 1 and friendly energy supply (solar energy). Supplying fresh and healthy water is still one of the major problems in different parts of the world, especially in arid remote areas. Solar stills can solve a part of the problem in those areas where solar energy is available. These units can be placed at each house for producing at least drinking water (Arjunan $\boldsymbol{e t}$ al., 2009). Solar desalination is a process of separating pure water from saline water using solar energy (Sakthivel et al., 2010).

*Associate Prof. and **Lecturer of Agric. Eng. Dep., Fac. of Agric., Suez Canal Univ., 41522 Ismailia, Egypt. 
Single slope solar stills are one of the solar devices used for fresh water production. They are considered as one of the cheapest solutions for purifying saline water and suitable for the Middle East and Africa due to their low cost and easily constructive approach and maintenance (Goosen et al., 2000). Single basin solar still is a very simple solar device used for converting available saline water into potable water. This device can be fabricated easily with locally available materials. For lower latitude places, double slope facing north and south direction still is preferred. Since for lower latitude regions, the sun rays are close to normal on south facing cover for a part of the year. For the remaining part of the year, sun rays are close to normal on north facing cover. The cover with inclination equal to latitude angle will receive the sun rays close to normal throughout the year. For places with latitude higher than $20^{\circ} \mathrm{N}$, single slope still is preferable. If the double slope still is used for the higher latitude places, only one side of the cover will receive the sun rays and the other side will be on the shadow side for sun rays. It was concluded that, the single slope solar still was found to be slightly more efficient and economic than the pyramid one (Fath et al., 2003). Kabeel et al. (2010) used different methods and modifications to improve the productivity of solar stills. The results showed that the best average and maximum daily productivity are obtained from solar stills of single and pyramid shapes. The efficiency of two basin type passive solar stills was developed by Eze and Ojike (2012). The results showed that, the rectangular-shaped solar still gave an average thermal efficiency of $36.8 \%$ while the pyramidshaped type performed $28.9 \%$ thermal efficiency. Hence the rectangularshaped solar still in comparison with the pyramid-shaped type is recommended for use to especially people living in coastal areas. Hashim et al. (2010) studied the productivity of fresh water by solar distillation using five different shapes of stills under the climatic conditions of Iraq at Basrah city to select the best shape. They found that the double slope solar still with glass cover inclination of $15^{\circ}$ and inner surface area of $1.1645 \mathrm{~m}^{2}$ is the best suited among the five models. A hemispherical and pyramid solar still was fabricated and tested by Arunkumer et al. (2012). They found that, the daily production of the hemispherical solar still was about $3.31 / \mathrm{m}^{2}$ per day and its daily thermal efficiency was about $32.02 \%$. 
Three different cover geometries were proposed, constructed and experimentally studied by Malaeb et al. (2014). These designs were double-sloped cover, curved cover and single-sloped cover. They found that, the water temperature during four months (May to August) in the basin was highest for the curved still, which showed the highest productivity during this period. Singh and Tiwari (2004) found that the annual yield of the solar still was maximized when the condensing glass cover inclination is equal to the latitude of the place. Abd Elkader (1998) found that the optimum inclined angle for solar still was $30-35^{\circ}$ for Port Said/Egypt (latitude angle of $31.2^{\circ} \mathrm{N}$ ). Murugavel et al. (2008) found that the solar still with glass cover plate with $3 \mathrm{~mm}$ thick gives $16.5 \%$ more production than that covered with $6 \mathrm{~mm}$ thick glass cover. The basin water depth is also having a significant effect on productivity of the basin. Experiments with deep basin reveal that the productivity of the still decreases with an increase in depth of water during daylight (Rajesh and Tiwari, 2005). The aim of the present work was to study the thermal performance of four different solar still roofs (single slope, downward slanting cover, double slope, and pyramidal solar still roofs) by comparing the productivity and other parameters under the climatic conditions of Ismailia city to select the best shape.

\section{MATERIALS AND METHODS}

\section{Experimental setup}

Four simple basin-type solar stills each having similar basin area and different roofs were constructed and tested at Agricultural Engineering Department, Faculty of Agriculture, Suez Canal University, Ismailia Governorate, Egypt (latitude angle of $30.62^{\circ} \mathrm{N}$, Longitude angle of $32.27^{\circ} \mathrm{E}$, and mean altitude above the sea level of $5 \mathrm{~m}$ ) to experimentally evaluate and compare the parameters affecting fresh water production. The tested solar stills were single slope, downward slanting cover, double slope and pyramidal solar stills. The conventional solar still consists of the following components: basin, wooden box and glass cover. The schematic diagram and the pictorial view of the solar distillation units are shown in Figs (1 and 2), respectively. Each one has a basin area of $0.42 \mathrm{~m}^{2}$ made of $1 \mathrm{~mm}$ galvanized iron sheet. All basins were painted by matt-type black to absorb the maximum amount of solar radiation 
incident on them. To prevent or minimize the heat loss from the base and the sides of the galvanized basin, the basin was fitted inside a wooden basin of an identical shape, but of a slightly larger size. The gaps between each wooden and galvanized basin were packed with $30 \mathrm{~mm}$ thick Styrofoam insulation (thermal conductivity of $0.037 \mathrm{Wm}^{-1} \mathrm{~K}^{-1}$ ). A clear glass cover of $3 \mathrm{~mm}$ thick was placed to cover all solar stills to transmit the maximum possible solar radiation flux incident on it (Singh and Tiwari, 2004). Glass covers have been framed with iron and sealed with silicone rubber. The geometric characteristics of single slope solar still are as follows: rafter length, $0.76 \mathrm{~m}$, maximum gable height, $0.60 \mathrm{~m}$ and vertical walls height are $0.22 \mathrm{~m}$ and $0.60 \mathrm{~m}$ for short and long sides, respectively. The schematic diagram of solar still with a downward slanting cover are as follows: downward slanting cover angle and length are $30^{\circ}$ and $0.36 \mathrm{~m}$, respectively, and height of each vertical wall is 0.43 $\mathrm{m}$. Meanwhile, the geometric characteristics of the double slope solar still are as follows: gable height $0.19 \mathrm{~m}$, rafter length, $0.38 \mathrm{~m}$ and height of each vertical wall is $0.25 \mathrm{~m}$. Finally, the geometric characteristics of the pyramidal solar still glass cover is formed of similar four triangle glass sheets with an inclination of $55^{\circ}$, triangle base and sides are $0.75 \mathrm{~m}$ and $0.65 \mathrm{~m}$, respectively. To collect the distilled water from the solar still, a trough made from PVC was placed along the bottom side of the glass cover with an inclination of $5^{\circ}$ towards the collecting head in order to speed up the condensate velocity and to avoid the tendency of reevaporation. The system has capability to collect distillates from all sides of the solar stills. A steel pipe is used to supply the saline water $(34,500$ ppm) fixed at the side wall of the still for feeding brackish water as shown in Figs (1 and 2). The technical specifications of the systems are given in Table (1).

\section{Measurements and data acquisition}

The experimental tests of this work were carried out from sunrise to sunset during July month of 2015. During the experiments, the temperatures for various locations (ambient air temperature, $\mathrm{T}_{\mathrm{a}}$, basin water temperature, $T_{w}$, still water vapour temperature, $T_{v}$, inside glass temperature, $\mathrm{T}_{\mathrm{gi}}$, and outside glass temperature, $\mathrm{T}_{\mathrm{go}}$ ) were recorded with the help of calibrated thermocouples. 


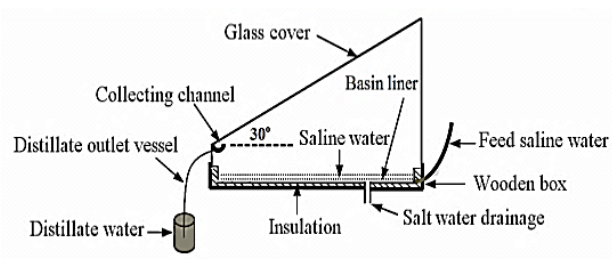

Single slope solar still

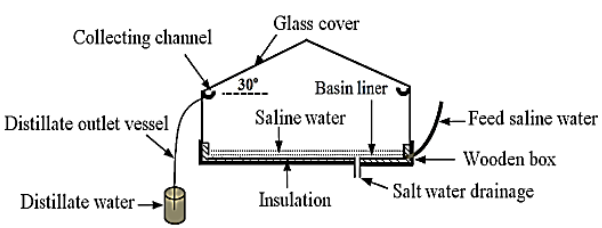

Double slope solar still

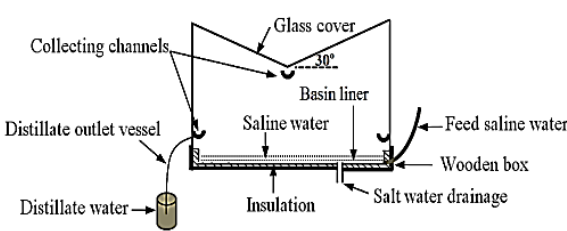

Downward slanting cover solar still

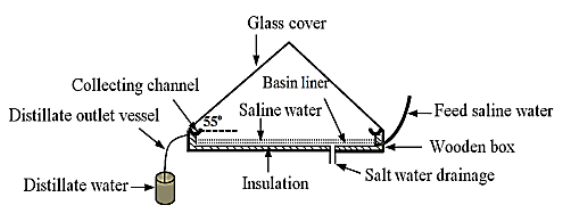

Pyramidal solar still

Fig. (1): Schematic diagram of experimental setup

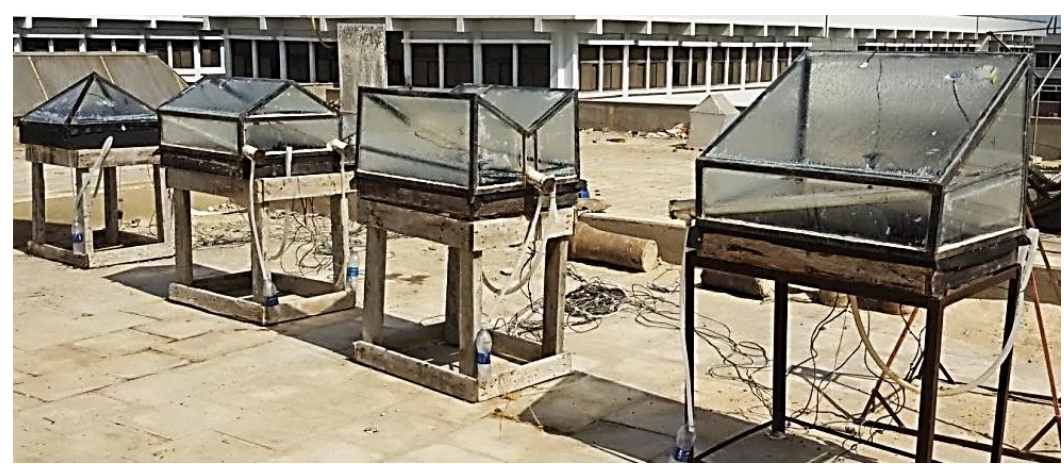

Fig. (2): Solar still shapes

Table (1): Technical specification of the solar stills

\begin{tabular}{||l|c|c|c|c||}
\hline \multicolumn{1}{|c|}{ Specification } & $\begin{array}{c}\text { Single } \\
\text { slope }\end{array}$ & $\begin{array}{c}\text { Downward } \\
\text { slanting } \\
\text { cover }\end{array}$ & Double slope & Pyramidal \\
\hline Basin dimension, $\mathrm{m}$ & $0.56 \times 0.75$ & $0.56 \times 0.75$ & $0.56 \times 0.75$ & $0.65 \times 0.65$ \\
\hline Basin area, $\mathrm{m}^{2}$ & 0.42 & 0.42 & 0.42 & 0.42 \\
\hline Glass cover area, $\mathrm{m}^{2}$ & 1.89 & 1.65 & 1.52 & 0.80 \\
\hline Glass cover volume, $\mathrm{m}^{3}$ & 0.23 & 0.26 & 0.40 & 0.19 \\
\hline Thickness of wood, $\mathrm{m}$ & 0.02 & 0.02 & 0.02 & 0.02 \\
\hline $\begin{array}{l}\text { Thermal conductivity of } \\
\text { wood, Wm } \mathrm{K}^{-1}\end{array}$ & 0.055 & 0.055 & 0.055 & 0.055 \\
\hline Thickness of Styrofoam, $\mathrm{m}$ & 0.03 & 0.03 & 0.03 & 0.03 \\
\hline $\begin{array}{l}\text { Thermal conductivity of } \\
\text { styrofoam, } \mathrm{Wm}^{-1} \mathrm{~K}^{-1}\end{array}$ & 0.037 & 0.037 & 0.037 & 0.037 \\
\hline
\end{tabular}


These sensors were connected to a data-logger system (Lab-Jack logger, powered by USB cable, supply 4-5.25 volt, USA) to display, and record the data during the experimental period. The output data were recorded every five minutes and averaged every one hour using the data logging program. All thermocouple sensors were calibrated with an electronic thermometer (-10 up to $100^{\circ} \mathrm{C}$ ). Meteorological station (Vantage Pro 2, Davis, USA) located above the roof of the Agricultural Engineering Department was used to measure different macroclimate variables such as the solar radiation flux incident on a horizontal surface (pyranometer), dry and wet-bulb temperatures, wind speed and its direction. Hourly distillated outputs for all stills were measured directly from graduated bottles of least count $1 \mathrm{ml}$. At this particular condition, experiments were conducted for three days, so that analysis and comparison could be done fairly under the same climatic condition and to get concurrent results (Arjunan et al., 2009).

\section{Thermal efficiency of the solar still}

The thermal efficiency of a solar still is defined as the ratio of the rate of heat transfer $\left(\mathrm{q}_{\mathrm{ev}}\right)$ in the still by evaporation-condensation $\left(\mathrm{Wm}^{-2}\right)$ to the solar radiation $(\mathrm{R})$ on the still $\left(\mathrm{Wm}^{-2}\right)$. It can be calculated by the following equation (ASHRAE, 2005; Duffie and Beckman, 2006):

$$
\eta_{\mathrm{vol}}=\frac{q_{e w}}{R}
$$

In practice, there is some loss of produced fresh water when it back into the basin of still (by dripping from the glass cover or leakage from collecting troughs), less product would be available than it is indicated by the above equation. Therefore, the thermal efficiency of the solar still from the experimental measurements (volumetric thermal efficiency) which represents the actual productivity of fresh water is mainly computed using the following equation (ASHRAE, 2005; Duffie and Beckman, 2006):

$$
\eta_{v o l}=\frac{m_{p} h_{f g}}{3.6 A_{b} R}
$$

Where, $\mathrm{m}_{\mathrm{p}}$, is the rate at which distillate of fresh water is produced from the still in $\mathrm{kg} \mathrm{h}^{-1}, \mathrm{~h}_{\mathrm{fg}}$, is the latent heat of vaporization in $\mathrm{kJ} \mathrm{kg}^{-1}, \mathrm{~A}_{\mathrm{b}}$, is the surface area of basin in $\mathrm{m}^{2}$, and $\mathrm{R}$, is the solar radiation flux incident on the basin in $\mathrm{W} \mathrm{m}^{-2}$. 


\section{RESULTS AND DISCUSSION}

For the duration of the experimental work, the four different configurations of solar still (single slope, downward slanting cover, double slope and pyramidal solar stills) were operated satisfactorily without malfunction. The measurements of solar radiation intensity, various temperatures, and the production of distilled water were taken each hour to study the effect of each parameter on the productivity of the solar stills. Ambient air temperature and solar radiation intensity during $8^{\text {th }}$ of July 2015 are shown in Fig. (3). The intensity of solar radiation was gradually increased from sunrise $\left(265 \mathrm{Wm}^{-2}\right)$ till reached the maximum value $\left(869 \mathrm{Wm}^{-2}\right)$ at $13.00 \mathrm{~h}$, then it gradually decreased until approached the minimum value $\left(136 \mathrm{Wm}^{-2}\right)$ prior to sunset. While, the ambient air temperature increased gradually from $25.2^{\circ} \mathrm{C}$ at $7.00 \mathrm{~h}$ until reached the maximum value $\left(36.2^{\circ} \mathrm{C}\right)$ at $13.00 \mathrm{~h}$, then it was decreased till reached $28.5^{\circ}$ at $19.00 \mathrm{~h}$. During the experimental period, the daily average ambient air temperature was $32.1^{\circ} \mathrm{C}$ and average solar radiation was $556.0 \mathrm{Wm}^{-2}$. This means that, the solar radiation almost at all times from sunrise to sunset was perpendicular to the surface particularly at and around noon, and consequently when the angle of incidence equal zero. These data are agreement with that published by (Abdallah and Badran, 2008).

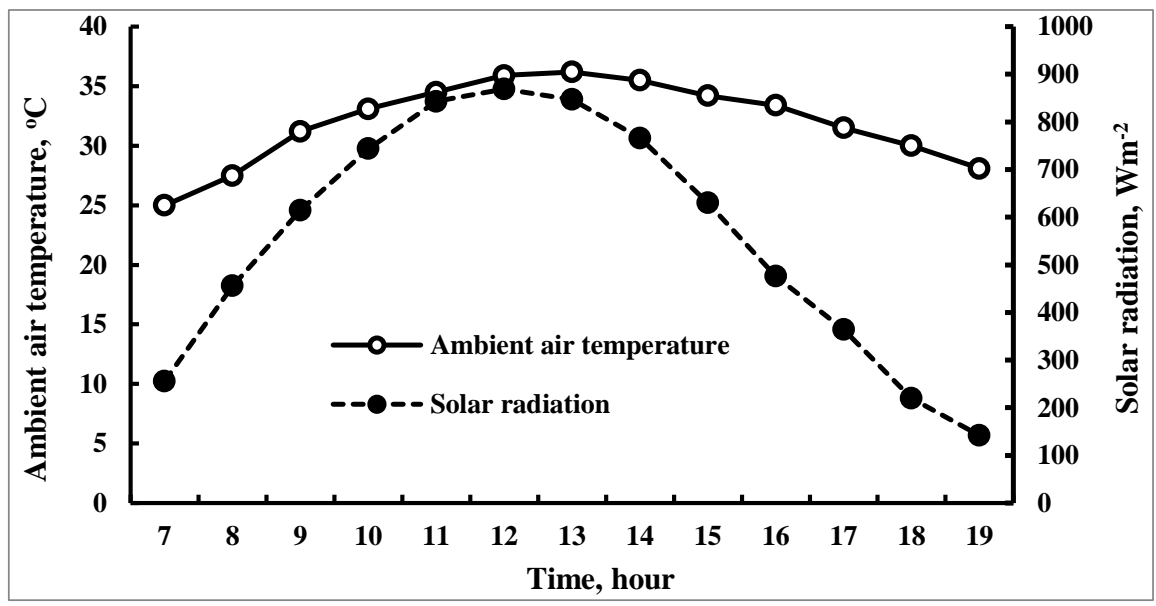

Fig. (3): Hourly average ambient air temperature and intensity of solar radiation for $8^{\text {th }}$ of July 2015 . 
Fig. (4) shows the saline water temperatures for the four different solar stills (single slope, downward slanting cover, double slope and pyramidal solar stills). The hourly average saline water temperatures for the four different solar stills were found to be $48.0,47.2,46.0$ and $44.8^{\circ} \mathrm{C}$ for the single slope, downward slanting cover, double slope and pyramidal solar stills, respectively. It can clearly be seen that, saline water temperatures increased for all tested solar stills to be reached the maximum values of $58.7,57.7^{\circ} \mathrm{C}, 55.0$ and $53.4^{\circ} \mathrm{C}$, respectively, afternoon $(13.00 \mathrm{~h})$ because they were absorbed the maximum amount of solar radiation. After 13.00 $\mathrm{h}$, saline water temperature decreased because the heat energy losses from the solar stills increased, particularly when the water temperatures were higher than the absorbed solar radiation. The water temperature depends strongly upon the other different parameters such as; the intensity of solar radiation, absorptivity of the water and black basin surface, cover shape, and temperature difference between the water vapour and inside surface of the solar still.

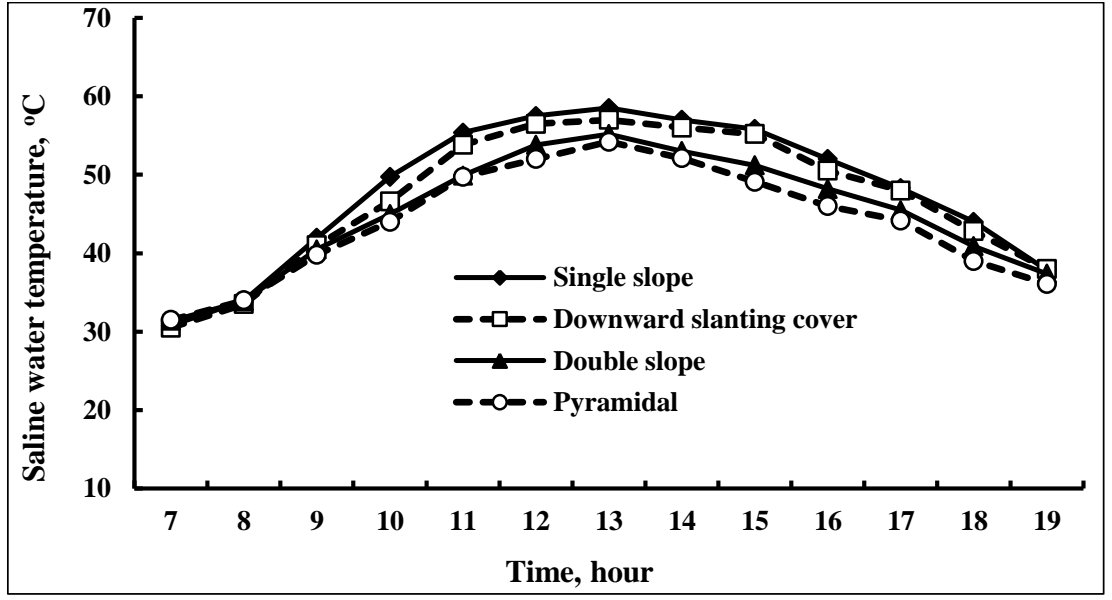

Fig. (4): Hourly average saline water temperature for the four different shapes of solar still covers.

The distributions of the hourly average water vapour temperatures of the four different solar stills were plotted in Fig. (5). The water vapour temperature had the highest temperature because the particles have enough heat energy to evaporate. The highest vapour temperature was achieved during the daylight-time (from sunrise to sunset) from the single slope solar still. It increased from $37.3^{\circ} \mathrm{C}$ at $7.00 \mathrm{~h}$ till it reached its pick 
of $62.2^{\circ} \mathrm{C}$ at $14.00 \mathrm{~h}$. It is noticed also that, the hourly average water vapour temperatures for the single slope, downward slanting cover, double slope and pyramidal solar stills, respectively, were 51.6, 49.1, 48.6 and $48.0{ }^{\circ} \mathrm{C}$. This means that, the normalized temperature rise $\left(\mathrm{D}_{\mathrm{T}}\right)$ of the water vapour temperature increased above the outside ambient air temperature per solar radiation flux incident on the solar still. It can be determined according to the equation (3). The normalized temperature rise were $0.034,0.031,0.030$ and $0.029^{\circ} \mathrm{C} \mathrm{Wm}^{-2}$ for the single slope, downward slanting cover, double slope and pyramidal solar stills, respectively.

$$
D_{T}=\left(\frac{T_{v}-T_{a}}{R}\right), \quad{ }^{o} \mathrm{C} / \mathrm{Wm}^{-2}
$$

Where, $\mathrm{T}_{\mathrm{v}}$, is the interior water vapour temperature in ${ }^{\circ} \mathrm{C}, \mathrm{T}_{\mathrm{a}}$, is the ambient air temperature in ${ }^{\circ} \mathrm{C}$, and, $\mathrm{R}$, is the solar radiation in $\mathrm{Wm}^{-2}$. In other words the single slope solar still increased the inside water vapour temperature by 5.1, 6.2 and 7.5\% above that for downward slanting cover, double slope and pyramidal solar stills, respectively.

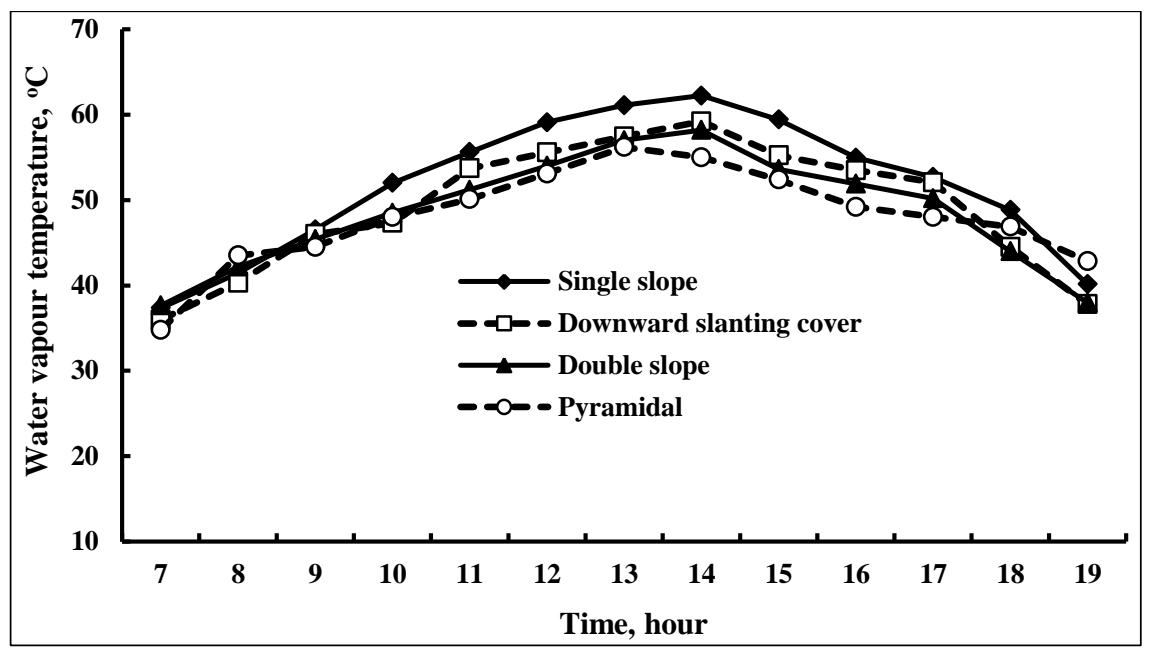

Fig. (5): Hourly average water vapour temperature distributions as affected by the solar still covering shape.

It can be observed that, the glass cover temperature was usually lower than that of water vapour temperature except in the early morning when 
the difference between them was very small as revealed in Fig. (6). As the glass cover temperature is lower than the water vapour temperature, much more condensation of water vapour on the internal surface of the glass cover occurred. In the early morning (from 7.00-8.00 h), the glass temperature was closest to the water vapour temperatures resulting in small productivity due to the small heat energy absorbed by the water at these times. The hourly average inner glass temperatures for solar stills were found to be $43.5,43.0,41.7$ and $40.9^{\circ} \mathrm{C}$ for the single slope, downward slanting cover, double slope and pyramidal solar stills, respectively. The difference in temperature between saline water and inner glass throughout the day for the four different solar stills is plotted in Fig. (7). It is clear that during early morning glass cover encountered the solar radiation first and its temperature rose very fast with time as compared with the rising in water temperature, and as a result the difference becomes negative. These differences remains negative till water temperature exceeded glass temperature. The maximum positive difference were found to be $7.5,7.1,6.1$ and $5.2^{\circ} \mathrm{C}$ which achieved at $14.00 \mathrm{~h}$ for the single slope, downward slanting cover, double slope and pyramidal solar stills, respectively, after that the difference decreases till the sunset.

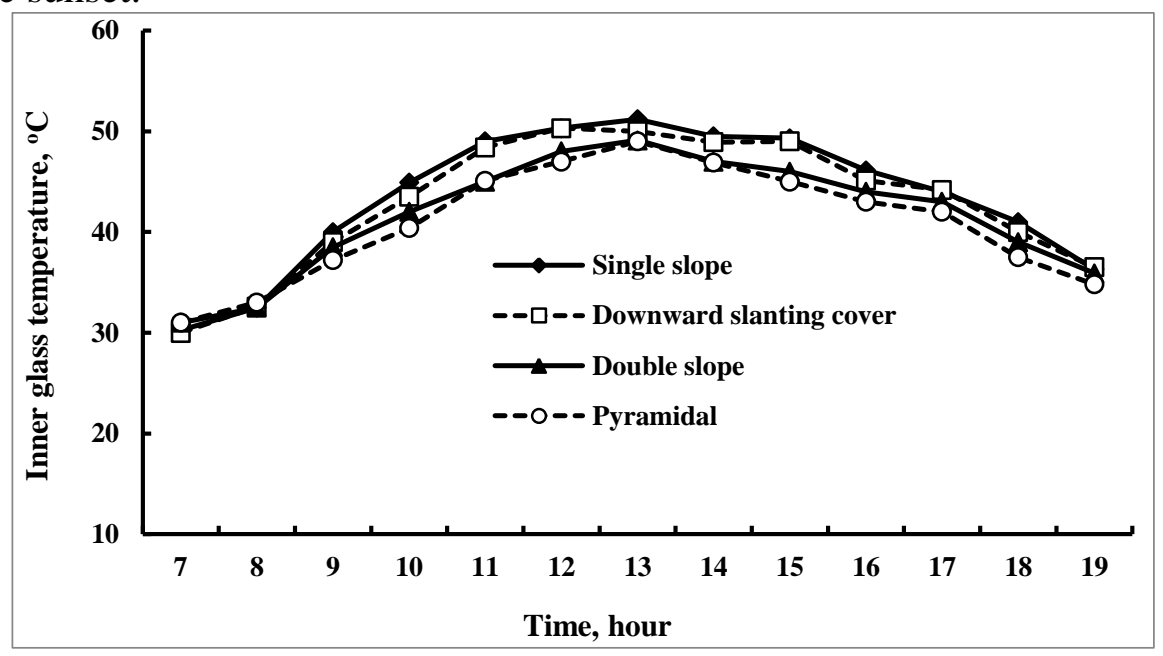

Fig. (6): Effect of the covering shape on the hourly average inner glass temperature as a function of solar time. 


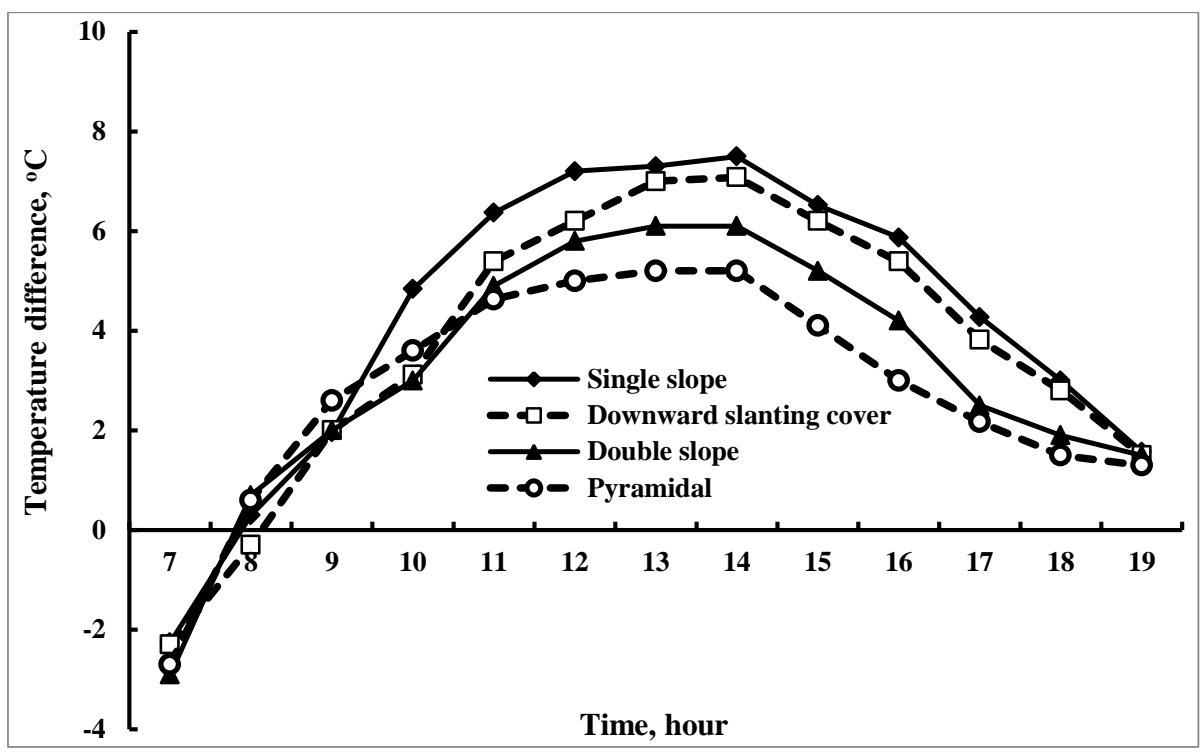

Fig. (7): Hourly average temperature difference between saline water and inner glass cover for all solar still as a function of solar time.

The economical productivity rate of fresh water reflects how much the solar stills were adapted to the covering treatments. The yields $\mathrm{ml} / \mathrm{hr}$ for the different solar still trials is shown in Fig. (8). The yield of fresh water was highly affected by the covering shape treatments. It can be seen that, the productivity of fresh water for the four different solar stills gradually increased from early morning until reached the maximum values (223, 211,165 and $147 \mathrm{ml} / \mathrm{hr}$, respectively) afternoon then they decreased till approached the minimum values $(45,43,36$ and $31 \mathrm{ml} / \mathrm{hr}$ ) just prior to sunset. The saline water temperature can be considered as one of the parameters that has a direct effect on the productivity of fresh water. Daily average production of fresh water under the four different solar stills (single slope, downward slanting cover, double slope and pyramidal solar stills), respectively, were $116,107,84$ and $72 \mathrm{ml} / \mathrm{hr}$. This means that, the single slope increased the average production by $8.5,38.1$ and $60.1 \%$ as compared with the downward slanting cover, double slope and pyramidal solar stills, respectively. As the intensity of the solar radiation inside the four different solar stills was increased, the productivity of 
fresh water increased due to the increase in heat energy gained by the saline water at which vaporization inside the stills increased.

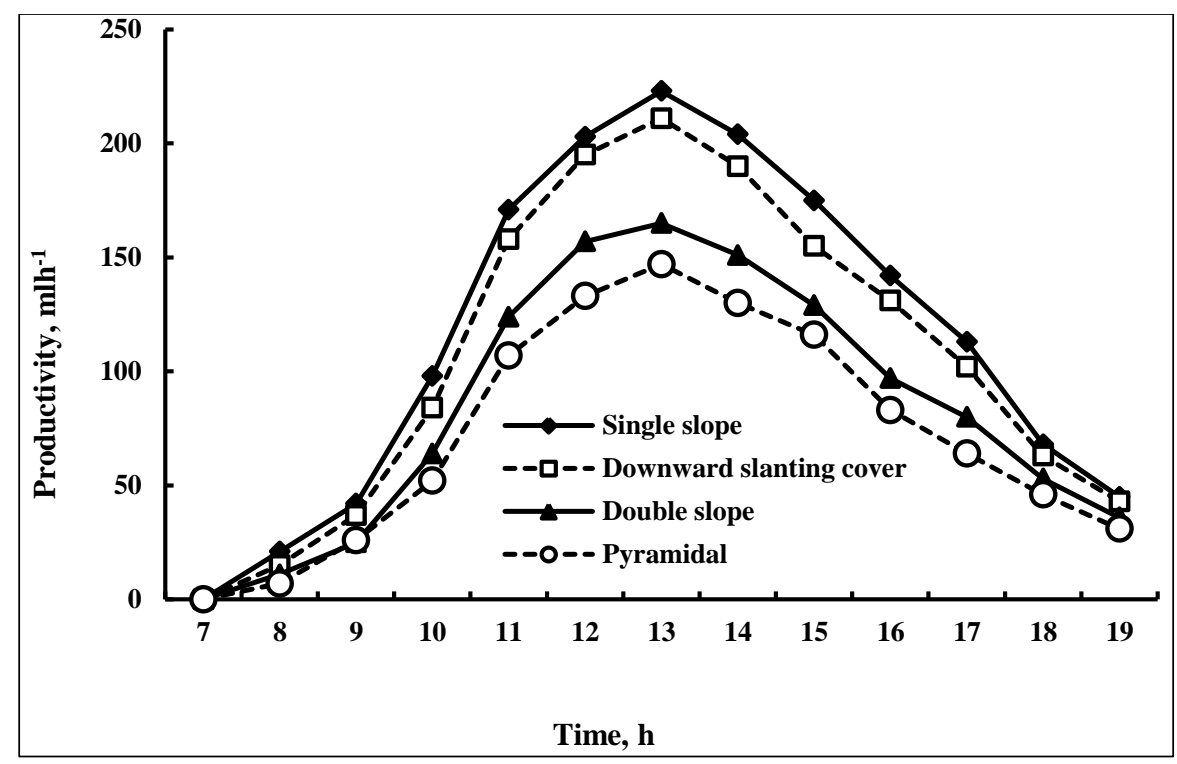

Fig. (8): Hourly average volumetric production rate as affected by the solar still covering treatments as a function of solar time.

The solar still volumetric thermal efficiency is considered as the most important parameter that affects productivity of fresh water. The hourly average volumetric thermal efficiencies for each solar still type within a representative day under the average weather conditions are plotted in Fig. (9). The volumetric thermal efficiencies for the four different configurations increased with the time until reaching the maximum value afternoon. In the morning, the temperature of saline water is low therefore it needs high energy to change its phase from saturated liquid to saturated vapour phase. The obtained results show that, the temperature and required heat are inversely proportional. Afternoon, the temperature of water reaches the maximum value so it needs less heat to vaporize. The average solar still volumetric efficiency were found to be 33.7, 31.0, 24.7 and $21.2 \%$ for the single slope, downward slanting cover, double slope and pyramidal solar stills, respectively. 


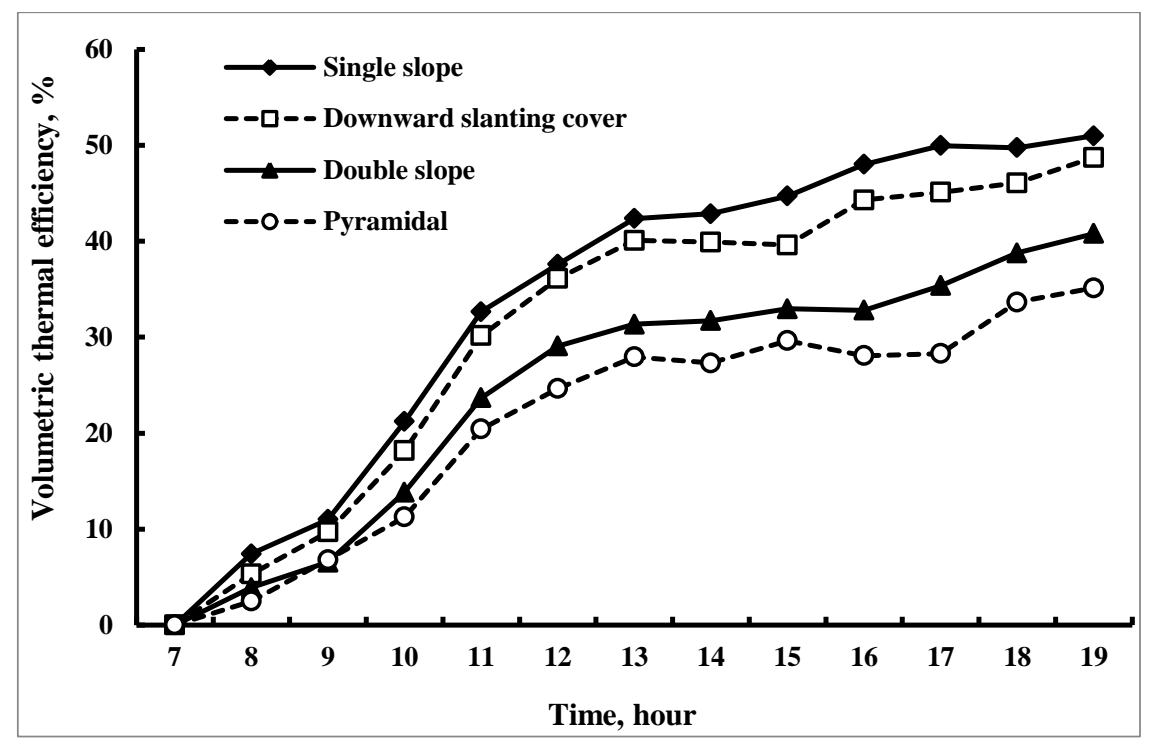

Fig. (9): Hourly average volumetric thermal efficiency versus time for the solar stills

\section{CONCLUSION}

In this present research work, several conclusions can be obtained and drawn as follows:

1- The hourly average saline water temperatures for the four different solar stills were found to be $48.0,47.2,46.0$ and $44.8^{\circ} \mathrm{C}$ for the single slope, downward slanting cover, double slope and pyramidal solar stills, respectively.

2- The highest water vapour temperature was obtained within the day time (from sunrise to sunset) for the single slope solar still. It was increased from $37.3^{\circ} \mathrm{C}$ at $7.00 \mathrm{~h}$ till it reached its pick value of $62.2^{\circ} \mathrm{C}$ at $14.00 \mathrm{~h}$ afternoon. The hourly average water vapour temperatures were $51.6,49.1,48.6$ and $48.0^{\circ} \mathrm{C}$ for the single slope, downward slanting cover, double slope and pyramidal solar stills, respectively.

3- The hourly average inner glass temperatures for the four different solar stills were $43.5,43.0,41.7$ and $40.9^{\circ} \mathrm{C}$, respectively. 
4- Daily average fresh water production from the four different solar stills was $116,107,84$ and $72 \mathrm{ml} / \mathrm{hr}$, respectively. This means that, the single slope increased the production of fresh water by $8.5,38.1$ and $60.1 \%$ as compared with the downward slanting cover, double slope and pyramidal solar stills, respectively.

5- The volumetric thermal efficiencies for the four different configurations increased with time until reaching the maximum value afternoon. The hourly average solar still thermal efficiency was 33.7, 31.0, 24.7 and $21.2 \%$ for the single slope, downward slanting cover, double slope and pyramidal solar stills, respectively.

\section{REFERENCES}

Abd Elkader, M. (1998) "An investigation of the parameters involved in simple solar still with inclined yute" Renew Energy, 14: 333-338

Abdallah, S.; and Badran, O. O. (2008) "Sun tracking system for productivity enhancement of solar still" Desalination, 220: 669-676

Arjunan1, T. V.; Aybar, H. S.; Nedunchezhian, N.; and Sakthivel, M. (2009) "Effect of Blue Metal Stones on the Performance of a Conventional Solar Still" Journal of Convergence in Engineering, Technology and Science, 1: 17-22

Arunkumara, T.; Jayaprakasha, R.; and Ahsanb, A. (2012) "A comparative experimental testing in enhancement of the efficiency of pyramid solar still and hemispherical solar still" International Journal of Renewable Energy, 7: 2

ASHRAE, (2005) "Handbook of Fundamentals" American Society of Heating, Refrigerating and Air Conditioning Engineers, New York, USA

Duffie, J. A.; and Beckman, W. A. (2006) "Solar Engineering of Thermal Processes" New York, N.Y., John Wiley and Sons 
Eze, J. I.; and Ojike, O. (2012) "Comparative evaluation of rectangular and pyramid-shaped solar stills using saline water" International Journal of the Physical Sciences, 7, 31: 5202-5208

Fath, H. E. S.; El-Samanoudy, M.; Fahmy, K.; and Hassabou, A. (2003) "Thermal-economic analysis and comparison between pyramid-shaped and single slope solar still configurations" Desalination, 159: 69-79

Goosen, M. F. A.; Sablani, S. S.; Shayya, W. H.; Paton, C.; and AlHinai, H. (2000) "Thermodynamic and economic considerations in solar desalination" Desalination, 129: 63-89

Hashim, A. Y.; Al-Asadi, J. M.; and Alramdhan, W. A. T. (2010) "An attempt to solar still productivity optimization; solar still shape, glass cover inclination and inner surface area of a single basin solar still, optimization" Basrah Journal of Scienec, 28, 1: 39-48

Kabeel, A. E.; Hamed, A. M.; and El-Agouz, S. A. (2010) "Cost analysis different solar still configurations" Energy, 35: 2901-2908

Malaeb, L.; Ayoub, G. M.; and Al-Hindic, M. (2014) "The effect of cover geometry on the productivity of a modified solar still desalination unit" Energy Procedia, 50: 406-413

Murugavel, K. K.; Chockalingam, Kn. K. S. K.; and Srithar, K. (2008) "Progresses in improving the effectiveness of the single basin passive solar still" Desalination, 220: 677-686

Rajesh, T.; and Tiwari, G. N. (2005) "Effect of water depth on internal heat and mass transfer for active solar distillation" Desalination, 173: $187-200$.

Sakthivel, M.; Shanmugasundaram S.; and Alwarsamy, T. (2010) "An experimental study on a regenerative solar still with energy storage medium Jute cloth" Desalination, 264: 24-31

Singh, H. N.; and Tiwari, G. N. (2004) "Monthly performance of passive and active solar stills for different Indian climatic conditions" Desalination, 168: 145-150 


\section{الملخص العربي}

\section{تآثير أنماط مختلفة لثكل السقف على الأداء الحرارى للمقطرات الثمسية إسلام حسن الثيخ 'و سامح سعيد كثك '}

أجري هذا البحث بقسم الهندسة الزر اعية ـ كلية الزر اعة ـ جامعة قناة السويس ويهدف إلي تقييم

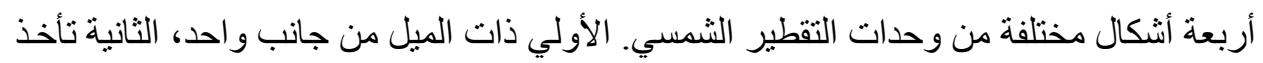

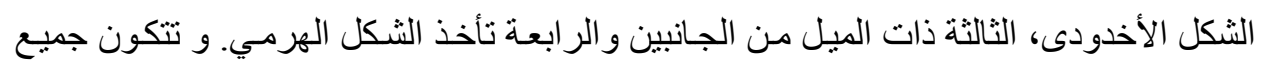

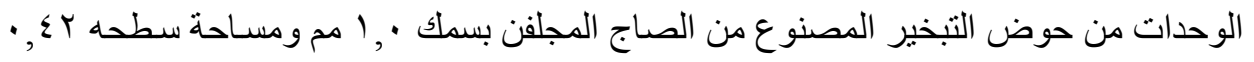

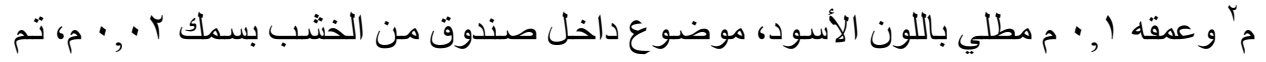

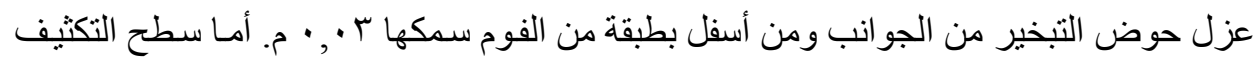

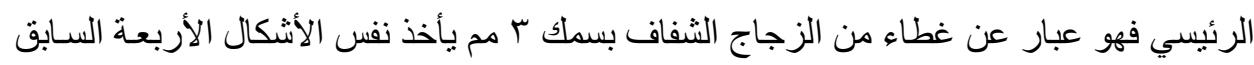
ذكر ها. ويتم تجميع القطر ات المتكاثفة عن طريق قنوات التجميع الموجودة أسفل الغطاء في جميع

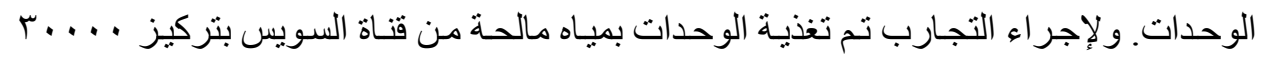
جزء في المليون.

\section{وقد أوضحت التتائج مايلي:}

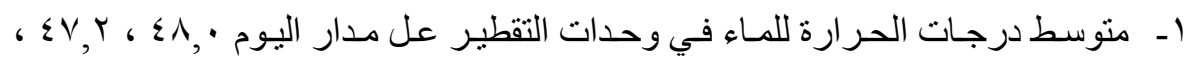

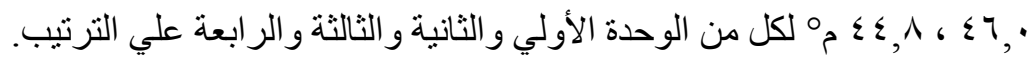

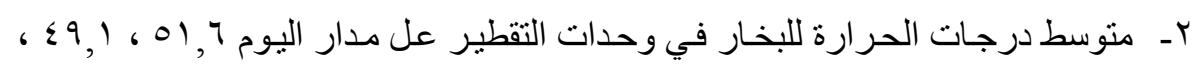

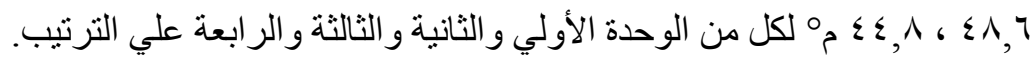

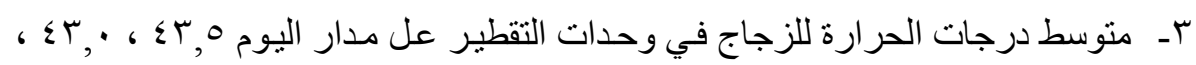

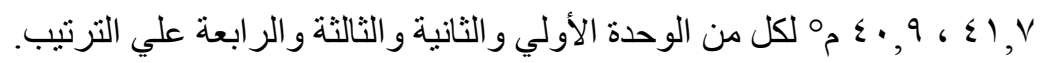

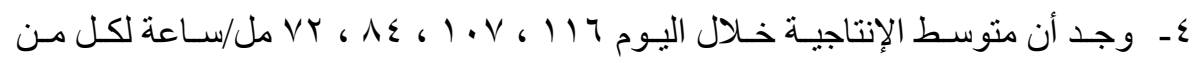

الوحدة الأولي و الثانية و الثالثة و الر ابعة علي الترنيب.

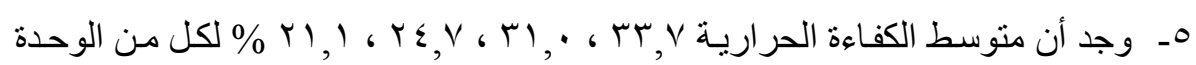

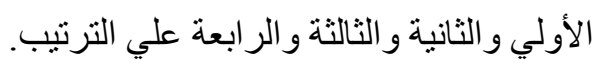

' أستاذ مساعد ـ قسم الهندسة الزراعية ـ كلية الزراعة ـ جامعة قناة السويس.

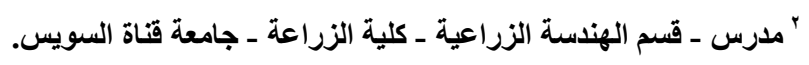

